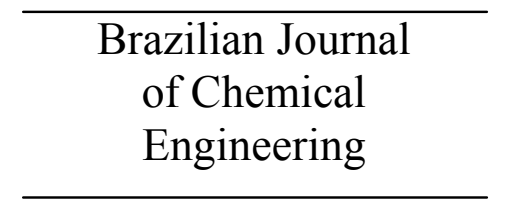

ISSN 0104-6632

Printed in Brazil

www.abeq.org.br/bjche

Vol. 28, No. 04, pp. 597 - 604, October - December, 2011

\title{
ETHANOL PRODUCTION FROM SORGHUM GRAINS [Sorghum bicolor (L.) MOENCH]: EVALUATION OF THE ENZYMATIC HYDROLYSIS AND THE HYDROLYSATE FERMENTABILITY
}

\author{
C. A. Barcelos, R. N. Maeda, G. J. V. Betancur and N. Pereira Jr. \\ Laboratories of Bioprocess Development, Department of Biochemical Engineering, \\ School of Chemistry, Center of Technology, Phone: + (55) (21) 2562-7646, Fax: + (55) (21) 25627616 , \\ Federal University of Rio de Janeiro, Building E-121, Zip Code: 21949-900, Rio de Janeiro - RJ, Brazil. \\ E-mail: nei@eq.ufrj.br
}

(Submitted: February 7, 2011 ; Revised: May 19, 2011 ; Accepted: July 26, 2011)

\begin{abstract}
The production of ethanol from sorghum grains was investigated in the present work. Initially, starch enzymatic hydrolysis was investigated using commercial $\alpha$-amylase and glucoamylase, considering particle size, solid:liquid ratio and enzyme load as variables. The hydrolysate, in the best conditions ( $73 \mathrm{U}$ of $\alpha$-amylase/g grain and $1150 \mathrm{U}$ glucoamylase/g grain), contained glucose at a concentration of approximately $250 \mathrm{~g} / \mathrm{L}$, which was fermented to produce ethanol in a bioreactor in batch mode. Using an industrial strain of Saccharomyces cerevisiae, the maximum ethanol concentration produced was roughly 106 g. $\mathrm{L}^{-1}$ in $24 \mathrm{~h}$ of fermentation, resulting in a volumetric productivity of $4.4 \mathrm{~g} \cdot \mathrm{L}^{-1} \cdot \mathrm{h}^{-1}$ and a product yield based on the substrate consumed $\left(0.499 \mathrm{g.g}^{-1}\right)$ close to the theoretical.

Keywords: Sorghum Grains; Enzymatic Hydrolysis; Ethanol; Fermentation; Saccharomyces cerevisiae.
\end{abstract}

\section{INTRODUCTION}

Ethanol has been pointed out as a solution for a variety of complex problems related to energy and environmental issues (Altintaş et al., 2002). Currently, sugarcane is indicated as the most competitive feedstock for first generation ethanol production; however, this feature is restricted to certain climatic conditions and soil types.

Sorghum [Sorghum bicolor (L.) Moench] is considered to be a viable and renewable feedstock (i.e., technically acceptable, fits the infrastructure, and can be economically viable) for ethanol production, which can make a large contribution to the ethanol-producing nations (Farrell et al., 2006; Rooney et al., 2007; Wu et al., 2006; Wu et al., 2007).
Sorghum is an important drought-resistant cereal crop, originally from Africa, which is ranked as the fifth largest produced cereal in the world after wheat, rice, barley and corn (Shewale and Pandit, 2009). In Africa, China and India, sorghum is a staple food, while in the United States, Australia and South America it is used for animal feed (Belton and Taylor, 2004). In some areas of Brazil, sorghum has been increasingly planted during the dry season between crops of soybeans or cotton.

Sorghum is valued because of its ability to grow in areas with marginal rainfall and high temperatures (i.e., in semiarid tropical and subtropical regions of the world) where it is difficult to grow any other cereal. Also, because of its relatively short growing season requirements, it is suitable for double

*To whom correspondence should be addressed 
cropping and crop rotation systems (Smith and Frederiksen, 2000). Sorghum has a relatively low cash value if sold directly as feed grain (Fang and Hanna, 2002). To enhance the value of sorghum crops, new industrial uses need to be developed. Sorghum grain is one of the most important sources of carbohydrates. Carbohydrates and fibers comprise approximately $72 \%$ of sorghum grains (Wu et al., 2007). Its starch component has similar properties to corn starch, and can be used almost interchangeably. Since there are hundreds of sorghum hybrids available commercially, if these feedstocks are the option for bioethanol production, the large variations in their composition will surely affect the hydrolysis and fermentation performance (Wang et al., 2008). Thus, it is important for the ethanol industry and sorghum producers to have appropriate methods that accurately predict sorghum ethanol yields and conversion efficiencies (Zhao et al., 2009).

Although ethanol production from sugarcane in Brazil is a consolidated and successful process, it is an energy matrix focused on just one culture. In this context, it is necessary to search for other sources of raw materials for sustaining and consolidating the concept of renewable energy. Sorghum can be an alternative, both for Brazil and other countries, since it is a culture that adapts to different soil types and climate. Moreover, according to the BNDES (Banco Nacional de Desenvolvimento Econômico e Social) and UDOP (União dos Produtores de Bioenergia), the ethanol yield from sorghum grains is approximately five fold higher than the ethanol yield from sugar cane (sugar cane: $80 \mathrm{~L} /$ ton; sorghum grains: $450 \mathrm{~L} /$ ton).

Another advantage of sorghum compared to sugarcane is related to the stalks left over after juice extraction, which have a better biological quality and provide animal feed and/or organic manure because they are still rich in micronutrients (Almodares and Hadi, 2010).

Based on the present considerations, the aim of this work was to determine the best conditions for enzymatic hydrolysis of sorghum grains [Sorghum bicolor (L.) Moench] and to evaluate the hydrolysate fermentability for ethanol production using an industrial strain of Saccharomyces cerevisiae.

\section{MATERIALS AND METHODS}

\section{Feedstock, Enzymes and Yeast Strain}

Sorghum grain samples with a moisture content of $14 \%(\mathrm{w} / \mathrm{w})$ were kindly supplied by Monsanto do
Brasil Ltda (Uberlândia - MG, Brazil). The enzymes used in this study were commercial $\alpha$-amylase from Bacillus licheniformis and glucoamylase from Aspergillus niger, both donated by LNF Latino Americana (Bento Gonçalves - RS, Brazil), and cellulase from Trichoderma reesei, obtained from Novozymes Latin America Ltda. The fermentative agent employed was an industrial strain of Saccharomyces cerevisiae (JP1) isolated from a distillery, Japungu Agroindustrial (Santa Rita - PB, Brazil) (Silva-Filho et al., 2005).

\section{Analysis of Particle Size}

Particle size analysis was performed using a Mechanical sieve shaker (Bertel - SP, Brazil). The particles were classified in standard sieves with several mesh sizes $(10-400)$ and particle size was described by the Sauter mean diameter (Fiori et al., 2008).

$$
\text { Smd }=\frac{1}{\sum_{j=1}^{N} \frac{\omega j}{d_{p, j}}}
$$

where Smd: Sauter mean diameter (mm); j: subscript indicating the $\mathrm{j}$-th granulometric class; $\mathrm{w}_{\mathrm{j}}$ : weight fraction; $\mathrm{d}_{\mathrm{p}}$ : particle diameter $(\mathrm{mm})$; $\mathrm{N}$ : number of granulometric classes.

\section{Analytical Assays}

For quantitative determination of reducing sugars (RS), the Somogyi and Nelson method described by Southgate (1991) was used. A standard curve was obtained by upon measuring the absorbance at $510 \mathrm{~nm}$ (Spectrumlab model-22PC spectrophotometer) of known concentrations of glucose solutions.

The concentrations of ethanol, glucose, maltose and glycerol were determined by high-performance liquid chromatography (HPLC - Waters, Milford, MA, U.S.A.) with a refractive index detector. The column used for separation was $\mathrm{SC} 1011$ at $80^{\circ} \mathrm{C}$ (Waters Milford, MA, USA). The HPLC apparatus with RI detector $\left(40^{\circ} \mathrm{C}\right)$ was operated with milliQ water at a flow rate of $0.6 \mathrm{~mL} \cdot \mathrm{min}^{-1}$ as the mobile phase.

\section{Starch Content of Dried Sorghum Grains}

The starch content of dried sorghum grains was determined through a quantitative enzymatic hydrolysis using commercial cellulases, $\alpha$-amylase and glucoamylase. Sorghum grains dried and milled to $0.5 \mathrm{~mm}$ mesh diameter were suspended in water at a 
concentration of $2.0 \%(\mathrm{w} / \mathrm{v})$. The $\mathrm{pH}$ of the grainwater mixture was adjusted to 5.0 with $7.5 \% \mathrm{H}_{2} \mathrm{SO}_{4}$ $(\mathrm{v} / \mathrm{v})$ and the cellulases were used in the ratio of $1 \mathrm{~mL} . \mathrm{g}^{-1}$ dry grain at $200 \mathrm{U} \cdot \mathrm{mL}^{-1}$ to release the starch stuck in the pericarp of sorghum grain. Hydrolysis with cellulases was performed at $50^{\circ} \mathrm{C}$ for $72 \mathrm{~h}$ before subsequent starch hydrolysis. The $\mathrm{pH}$ of the suspension was adjusted to 6.0 with $2 \mathrm{M} \mathrm{NaOH}$ and $\alpha$ amylase was added in the ratio of $1 \mathrm{~mL} \cdot \mathrm{g}^{-1}$ dry grain. The hydrolysis was carried out at $90^{\circ} \mathrm{C}$ for $2 \mathrm{~h}$. Thereafter, the temperature of the mixture was reduced to $55^{\circ} \mathrm{C}$ and the $\mathrm{pH}$ was adjusted to 4.5 using $7.5 \%$ $\mathrm{H}_{2} \mathrm{SO}_{4}(\mathrm{v} / \mathrm{v})$. Glucoamylase was then added in the ratio of $1 \mathrm{~mL} \cdot \mathrm{g}^{-1}$ dry grain and the hydrolysis was carried out at $55^{\circ} \mathrm{C}$ for $24 \mathrm{~h}$. Three parallel determinations were carried out under the same conditions described above in order to quantify the free sugars present in the grain-water mixture without enzymes (blank), the reducing sugars content in the enzyme blend (control 1) and the reducing sugars released by the action of cellulases on the shell of the grains (control 2). Starch content in sorghum grain was calculated as follows:

$$
\begin{aligned}
& (\%) \operatorname{Starch}_{\text {dryweight }}(\%)= \\
& \frac{[\mathrm{TRS}-(\mathrm{RSB}+\mathrm{RSC} 1+\mathrm{RSC} 2)] \times 0.9 \times \mathrm{V}_{\mathrm{t}} \times 100}{\mathrm{DGW}}
\end{aligned}
$$

\section{Enzymatic Assays}

The enzymatic activity of $\alpha$-amylase and glucoamylase was measured with the method used by Fuwa (1954) and Summer (1929), respectively.

\section{Determination of Yeast Cell Concentration}

The cell concentration was calculated by measuring the optical density at $600 \mathrm{~nm}$ using a Spectrumlab 22PC spectrophotometer (Shanghai Lengguang Technology Co. Ltd., Shanghai, China). The samples were diluted until the optical densities were within the linear range of the calibration curve (absorbance of 0.88 , which corresponds to 0.5 g. $\mathrm{L}^{-1}$ of cells). Dry cell weight was determined by filtering the cell suspensions through a $0.22 \mu \mathrm{m}$ membrane filter, followed by drying the filters at $105^{\circ} \mathrm{C}$ in a Moisture Analyzer (IV2000 GEHAKA - SP, Brazil).

\section{Establishment of Conditions for Hydrolysis of Sorghum Grains}

For the enzymatic hydrolysis of sorghum grains, the effect of the following variables were evaluated: particle size $(0.7,0.5$ and $0.3 \mathrm{~mm})$; solid:liquid ratio $(1: 7,1: 5,1: 4$ and $1: 3 \mathrm{~g}$ of grain per liquid media) and enzyme load of $\alpha$-amylase and glucoamylase $(0,20$, $40,60,80$ and $100 \mu \mathrm{L}$ per $\mathrm{g}$ of grain) with 3654 and $28724 \mathrm{U} \cdot \mathrm{mL}^{-1}$ of enzymatic activity, respectively. The temperature of $\alpha$-amylase and glucoamylase was kept constant at $90^{\circ} \mathrm{C}$ and $55^{\circ} \mathrm{C}$, respectively, and the hydrolysis time was $30 \mathrm{~min}$ for each enzyme. The $\mathrm{pH}$ used for each enzyme was 4.5 for glucoamylase and 6.0 for $\alpha$-amylase.

\section{Hydrolysis of the Sorghum Grains Under the Best Condition}

To determine the best conditions for starch enzymatic hydrolysis in different conditions, wet-milled sorghum grains $(1.0 \mathrm{~g})$ were added to test tubes. Suspensions containing water, $\alpha$-amylase and grains were incubated at $90^{\circ} \mathrm{C}$ and stirred periodically during $30 \mathrm{~min}$. These mixtures were subsequently cooled down to $55^{\circ} \mathrm{C}$ and glucoamylase was added to the test tubes. Temperature was kept constant for 30 min for complete starch saccharification. At the end of the reaction, the hydrolysate was centrifuged and reducing sugars in the supernatant were determined by the Somogyi and Nelson method. This value was used to determine the highest sugars concentration with the lowest enzyme load. All reactions were performed in duplicate. In addition, the kinetic profile of the enzymatic hydrolysis in the best condition was carried out in a larger volume $(2 \mathrm{~L})$ in order to obtain the hydrolysate for the fermentation step. Additionally, the concentrations of maltose and glucose were determined by high-performance liquid chromatography (HPLC - Waters, Milford, MA, U.S.A.).

The conversion efficiency of the hydrolysis was calculated as follows:

$\mathrm{CE}(\%)=\frac{\mathrm{RSP}}{\mathrm{TRS} \times 1.11} \times 100$

where the factor 1.11 is used to adjust the weight gain upon hydrolyzing starch to glucose.

\section{Inoculum Preparation}

An industrial strain of Saccharomyces cerevisiae (JP1) was used and maintained at $4{ }^{\circ} \mathrm{C}$ on YED medium containing $1 \%$ yeast extract, $2 \%$ glucose, $1.5 \%$ agar at $\mathrm{pH}$ 6.0. The cellular growth was performed in two steps. First, the yeast cells were cultured aerobically in a rotatory shaker (New 
Brunswick Scientific - Edison N. J., U.S.A.) at $37^{\circ} \mathrm{C}, \mathrm{pH} 4.5$ for $16 \mathrm{~h}$ at $200 \mathrm{rpm}$ in a medium containing 20 g. $\mathrm{L}^{-1}$ glucose, 1.25 g. $\mathrm{L}^{-1}$ urea, 1.1 g.L $\mathrm{L}^{-1}$ $\mathrm{KH}_{2} \mathrm{PO}_{4}, 2$ g. $\mathrm{L}^{-1}$ yeast extract and $40 \mathrm{~mL} . \mathrm{L}^{-1}$ of a solution of mineral salts described by Pereira Jr. and Bu'lock (1994). Then, the preculture was grown aerobically in conical flasks with $200 \mathrm{~mL}$ of the same medium used in the previous cultivation and was inoculated with a yeast suspension of $3.0 \mathrm{~g} \mathrm{d.w} / \mathrm{L}$ of cells. The inoculated flasks were incubated in a rotary shaker at $37^{\circ} \mathrm{C}$ for $8 \mathrm{~h}$ at $200 \mathrm{rpm}$. After this, the cells were aseptically centrifuged $(5,000 \mathrm{~g} / 40 \mathrm{~min})$ and the biophase was used to inoculate the hydrolysate of sorghum grains.

\section{Fermentation Assay and Monitoring of the Process}

The experiment was carried out using the hydrolysate of sorghum grains as the fermentation medium with no supplementation. Saccharomyces cerevisiae (JP1) was used as the fermentative agent to produce ethanol, batchwise in a Biostat $\mathrm{B}$ reactor (B. Braun Biotech International - Germany). The 4 L-bioreactor vessel was filled with $2.0 \mathrm{~L}$ of hydrolysate of sorghum grains and sterilized at $121^{\circ} \mathrm{C}$ for $30 \mathrm{~min}$. After cooling, the bioreactor was inoculated with an initial cell density of approximately $8.0 \mathrm{~g}$ (d.w.). $\mathrm{L}^{-1}$. The fermentation was conducted at $37^{\circ} \mathrm{C}$ with stirring at $300 \mathrm{rpm}$. The $\mathrm{pH}$ of the medium was maintained at 4.5 by addition of either $2 \mathrm{M} \mathrm{HCl}$ or $2 \mathrm{M} \mathrm{NaOH}$. The bioprocess was monitored and the kinetic profile of alcohol production and the substrate consumption were followed during $32 \mathrm{~h}$. The samples were taken and analyzed at regular intervals of time and were centrifuged at $12,000 \mathrm{rpm}$ for 15 minutes at $15^{\circ} \mathrm{C}$ (Sigma Laborzentrifugen 2K15). The supernatant was filtered (Millex-HV with membrane of PVDF pore of $0.45 \mu \mathrm{m}$ and diameter of $13 \mathrm{~mm}$ - Millipore) for ethanol and sugar measurements.

Fermentation efficiency was calculated as: (actual weight of alcohol produced/theoretical weight of alcohol produced from starch) $\mathrm{x} 100$. Ethanol productivity was expressed as $g$ of ethanol. $\mathrm{L}^{-1} \cdot \mathrm{h}^{-1}$.

Ethanol yield and volumetric ethanol productivity were calculated as follows:

$$
\begin{gathered}
\mathrm{Y}_{\mathrm{P} / \mathrm{S}}=\frac{\mathrm{P}-\mathrm{P}_{0}}{\mathrm{~S}_{0}-\mathrm{S}} \\
\mathrm{Q}_{\mathrm{P}}=\frac{\mathrm{P}-\mathrm{P}_{0}}{\mathrm{~T}_{\mathrm{f}}}
\end{gathered}
$$

\section{RESULTS AND DISCUSSION}

The starch content in sorghum grains was $79 \%$ (dry mass), which corresponds to $68 \%$ in wet mass.

Enzyme activities for $\alpha$-amylase at $90^{\circ} \mathrm{C}$ and glucoamylase at $55^{\circ} \mathrm{C}$ were $3654 \mathrm{U} \cdot \mathrm{mL}^{-1}$ and 28724 U. $\mathrm{mL}^{-1}$, respectively, which were quantified using acetate buffer and soluble potato starch as substrate.

\section{Effect of Particle Size}

The effect of particle size has typically been related to the available surface area for reactions (e.g., water binding, solubilization, heat transfer, and swelling) and enzymatic action (Al-Rabadi et al., 2009; Mahasukhonthachat et al., 2010). In order to evaluate the effect of particle size on enzymatic hydrolysis of sorghum grains, the following variables were fixed: solid:liquid ratio of $1: 7 \mathrm{~g} . \mathrm{mL}^{-1}, \alpha$-amylase load of $20 \mu \mathrm{L}$ per $\mathrm{g}$ of grains and temperature of glucoamylase at $55^{\circ} \mathrm{C}$. Fig. 1 shows that the reducing sugar concentration was the lowest for a particle size of $0.7 \mathrm{~mm}$, since the action of amylases was less favorable due to the lower availability of starch. In addition, the decrease of the particle size diminished the effect of diffusion limitation and led to a higher sugar yield in comparison with higher particle sizes. Considering this, when the particle size is smaller, there is a greater access of the enzymes to the starch macromolecules. The highest reducing sugar concentrations were achieved with the lowest particle size $(0.3 \mathrm{~mm})$. According to Wang et al. (2008), ethanol plants should grind the feedstock grains as fine as possible, balanced by grinding costs and avoidance of downstream process issues. Nonetheless, to obtain a particle size of $0.3 \mathrm{~mm}$, grains must be dried before milling to avoid clogging of the sieves, resulting in an increase in energy consumption. As a result, a particle size of $0.5 \mathrm{~mm}$ was chosen for further assays.

\section{Effect of Solid: Liquid Ratio}

Fig. 2 shows the effect of solid:liquid ratio (1:7, 1:5, 1:4 and 1:3 g.mL $\mathrm{mL}^{-1}$ ) on the enzymatic hydrolysis of sorghum grains in the following reaction conditions: $\alpha$-amylase load of $20 \mu \mathrm{L}$ per $\mathrm{g}$ of grain and particle size of $0.5 \mathrm{~mm}$. As the concentration of total solids increased, there was an increase in total sugars released. The maximum concentrations of reducing sugars were $\left(\mathrm{g} . \mathrm{L}^{-1}\right)$ : 92.3, 130, 135.0, 176.1 for a solid:liquid ratio of 1:7, 1:5, 1:4 and 1:3 g.mL respectively, which correspond to hydrolysis conversion efficiencies of $86.4 \%, 86.1 \%, 71.6 \%$ and 
$70 \%$. The high conversion efficiencies suggest that the enzyme can be used to hydrolyze effectively starch sorghum grains containing total solids ranging from $1: 7$ to $1: 3\left(\mathrm{~g} \cdot \mathrm{mL}^{-1}\right)$.

According to Zheng et al. (2009), a high concentrations of solids in a system with low water content may directly affect enzyme performance due to diffusion limitations, which was observed as a decrease in conversion efficiencies (experiments performed in test tubes). However, this can be eliminated by using larger volumes, as discussed further on. Therefore, a solid:liquid ratio of $1: 3 \mathrm{~g} \cdot \mathrm{mL}^{-1}$ was chosen as the best condition, since it provided the highest sugar concentration.

\section{Effect of Enzyme Load}

One of the factors that limits the use of enzymes is their high cost, representing a large portion of the total cost of the process. For this reason, different amounts of $\alpha$-amylase and glucoamylase were investigated in order to obtain the highest concentration of sugars using the lowest enzyme load. Fig. 3 shows experimental values of reducing sugars released during the enzymatic hydrolysis at a particle size of $0.5 \mathrm{~mm}$ and solid:liquid ratio of $1: 3 \mathrm{~g} \cdot \mathrm{mL}^{-1}$. The maximum concentrations of reducing sugars under $\alpha$-amylase loads of $0,20,40,60,80$ and $100 \mu \mathrm{L}$ per $\mathrm{g}$ of grain and varied glucoamylase load were (g.L $\left.\mathrm{L}^{-1}\right)$ : 92.9, $176.1,185.1,193.4,184$ and 190 , respectively. It is observed that, regardless of the glucoamylase load, amounts of $\alpha$-amylase above $20 \mu \mathrm{L}$ did not significantly improve the starch hydrolysis. In addition, considering the standard deviation, the response was similar for $\alpha$-amylase loads of up to $20 \mu \mathrm{L}$ per $\mathrm{g}$ of grain. As a result, the $\alpha$-amylase load of $20 \mu \mathrm{L}$ was chosen for starch liquefaction.

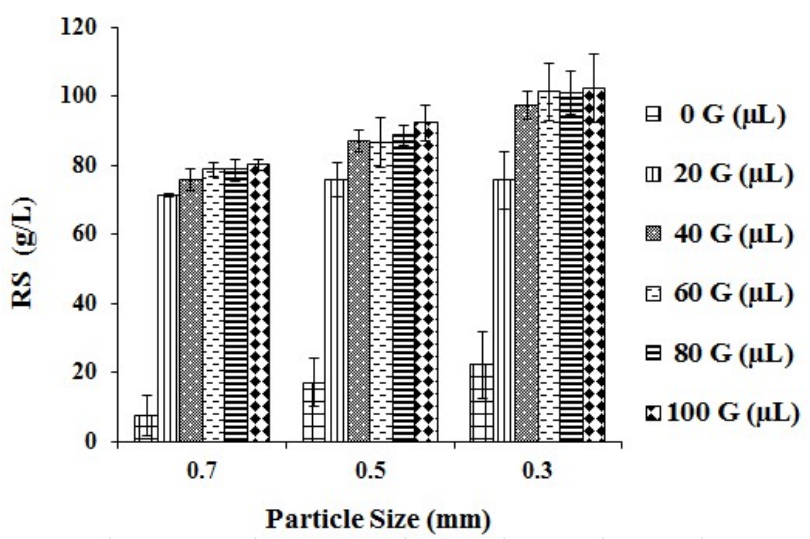

Figure 1: Effect of particle size on enzymatic hydrolysis of sorghum grains with solid:liquid ratio and $\alpha$-amylase fixed at $1: 7 \mathrm{~g} . \mathrm{mL}^{-1}$ and $20 \mu \mathrm{L} / \mathrm{g}$ of grain, respectively. RS: reducing sugars; G: glucoamylase.

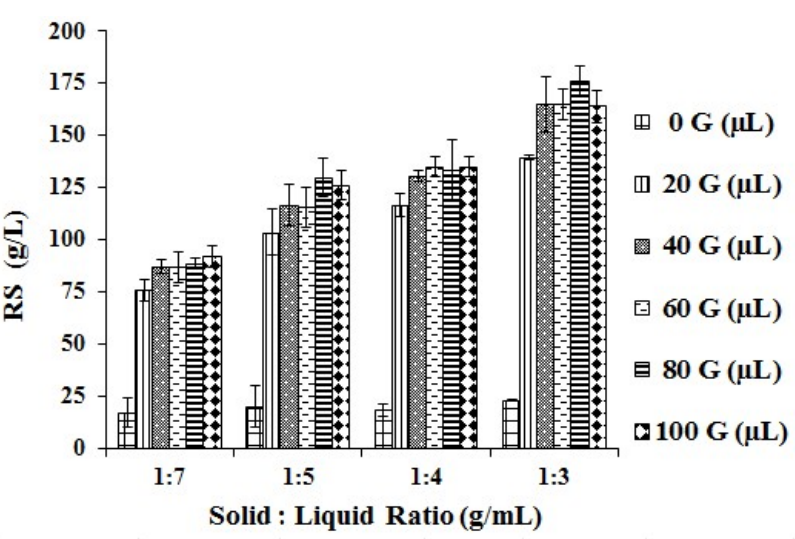

Figure 2: Effect of solid:liquid ratio on enzymatic hydrolysis of sorghum grains under a particle size of $0.5 \mathrm{~mm}$ and $20 \mu \mathrm{L} / \mathrm{g}$ of grain of $\alpha$-amylase. RS: reducing sugars; G: glucoamylase.

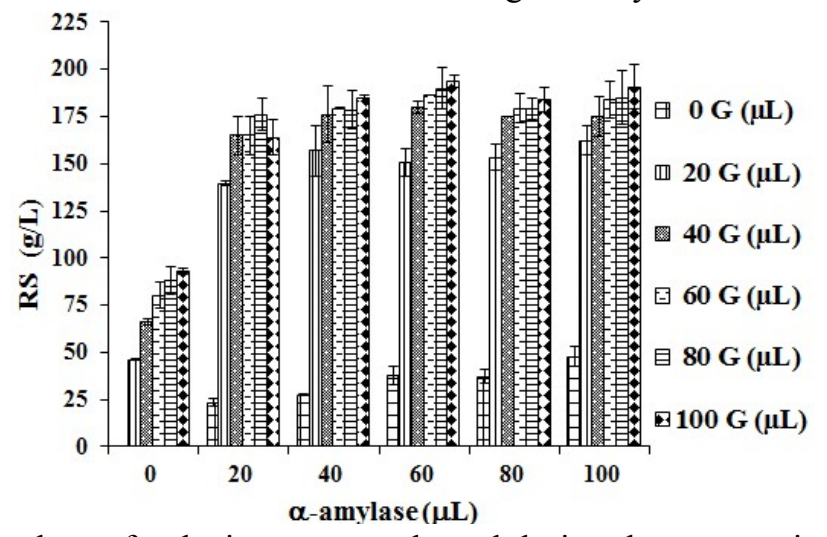

Figure 3: Experimental values of reducing sugars released during the enzymatic hydrolysis with particle size of $0.5 \mathrm{~mm}$ and solid:liquid ratio of $1: 3 \mathrm{~g} . \mathrm{mL}^{-1}$. RS: reducing sugars; G: glucoamylase. 
Concerning the saccharification action, the maximum concentrations of reducing sugars under glucoamylase loads of $0,20,40,60,80$ and $100 \mu \mathrm{L}$ per gram of grain were $\left(\right.$ g. $\left.\mathrm{L}^{-1}\right): 23.3,139.5$, 165.1, 165.0, 176.1 e 164.0, respectively, which corresponds to conversion efficiencies of 9.3, 55.9, $66.2,66.1,70.6$ e $65.8 \%$. It was clear that glucoamylase loads higher than $40 \mu \mathrm{L}$ did not significantly improve the concentration of reducing sugars. Bearing this in mind, a volume of glucoamylase of $40 \mu \mathrm{L}$ was chosen as the lowest load producing high concentrations of reducing sugars. High Performance Liquid Chromatography (HPLC) of the starch hydrolysate identified glucose as the main sugar, corresponding to more than $95 \%$ (data not shown).

\section{Ethanol Production}

A fermentation experiment was performed in the present work using an initial glucose concentration of 250 g.L. ${ }^{-1}$, which was obtained by enzymatic hydrolysis of sorghum grains under the following reaction conditions: $\alpha$-amylase load of $20 \mu \mathrm{L}$ per g of grain, glucoamylase load of $40 \mu \mathrm{L}$ per g of grain, particle size of $0.5 \mathrm{~mm}$ and solid:liquid ratio of $1: 3(\mathrm{~m} / \mathrm{v})$. The conversion efficiency for the enzymatic hydrolysis performed in a larger volume was $99.3 \%$ (Fig. 4) in relation to glucose, while in experiments in test tubes the conversion efficiency under the same reaction conditions was $66.2 \%$ due to diffusion limitations.

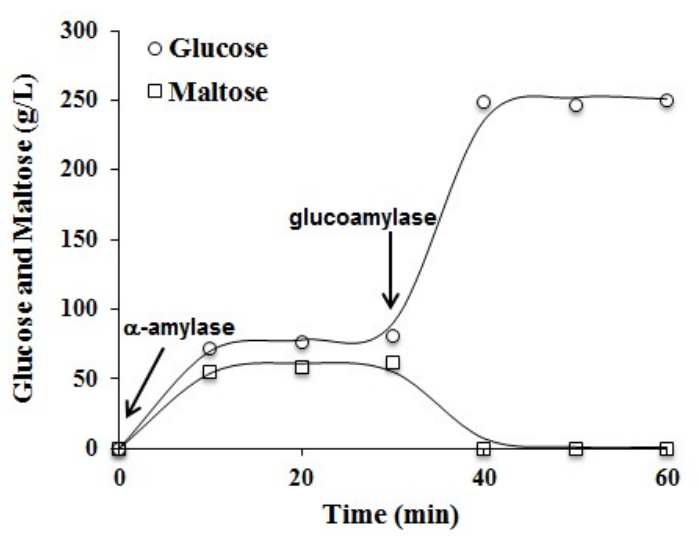

Figure 4: Kinetic profile of enzymatic hydrolysis of sorghum grains under the best conditions ( $\alpha$-amylase: $20 \mu \mathrm{L} / \mathrm{g}$ grain; glucoamylase: $40 \mu \mathrm{L} / \mathrm{g}$ grain); open circles, glucose; open squares, maltose. The arrows indicate the time at which the enzymes were added.

The kinetics of ethanol production and substrate consumption in a Biostat $\mathrm{B}$ reactor operated batchwise are shown in Fig. 5. An amount of $84.7 \%$ of the initial glucose was converted in $24 \mathrm{~h}$ of fermentation and the maximum ethanol concentration was 105.8 g. $\mathrm{L}^{-1}$ with a yield of $0.499 \mathrm{~g}$ ethanol per $\mathrm{g}$ of glucose consumed. This ethanol yield corresponds to $97.8 \%$ of the theoretical yield and a volumetric productivity of $4.41 \mathrm{~g} \cdot \mathrm{L}^{-1} \cdot \mathrm{h}^{-1}$. A stop in fermentation can be related to many factors, such as vitamin, magnesium, nitrogen and oxygen deficiencies. The effects related to these factors are numerous and include a decrease in $\mathrm{pH}$, inhibition of key enzyme activities, and alteration of the plasma membrane. These may induce a decrease in the metabolism of the yeast cell and, consequently, a decreases in biomass production, cell viability and fermentation rate. Furthermore, the occurrence of stuck and sluggish fermentation could be the result of interaction of these factors (Alexandre and Charpentier, 1998; Bisson, 1999). This phenomenon can be prevented by the addition of nutritional supplements to the hydrolysate (Ingledew and Kunkee, 1985; Lafon-Lafourcade et al., 1979).

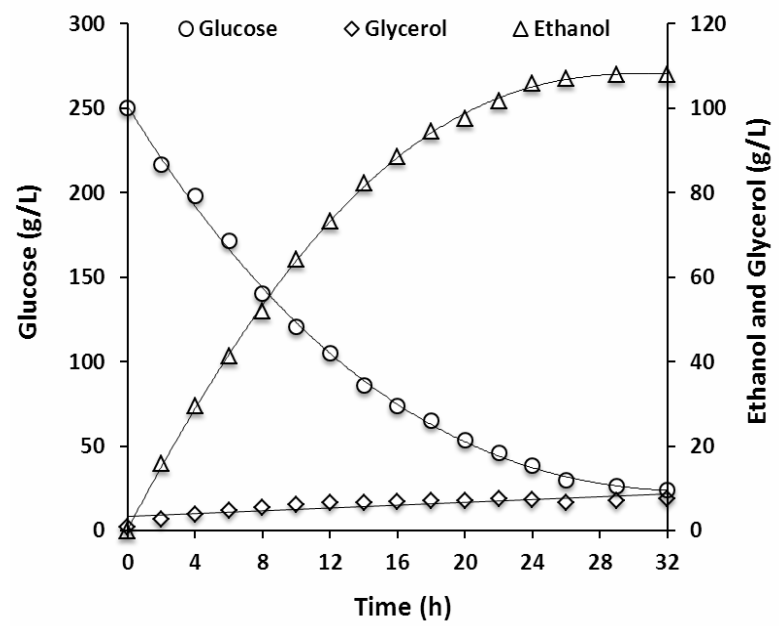

Figure 5: Time-course curves of ethanol production (open triangles), glucose uptake (open circles), and glycerol (open diamonds) for the fermentation of sorghum grains at $37^{\circ} \mathrm{C}$ by a strain JP1 of Saccharomyces cerevisiae using an initial glucose concentration of $250 \mathrm{~g} / \mathrm{L}$.

A small amount of glycerol was produced during the fermentation process, achieving $7.3 \mathrm{~g} . \mathrm{L}^{-1}$ at $24 \mathrm{~h}$ of fermentation. According to Xiaojing et al. (2008), glycerol is a major byproduct in anaerobic ethanol fermentation and consumes up to $4 \%$ of the total carbon source in the medium. The main physiological roles of glycerol formation are osmoregulation and maintaining redox balance (Hohmann, 2002).

The ethanol concentration attained in this study was similar to the values achieved in the current 
industrial production of ethanol from sugarcane. Therefore, sorghum presents the potential to complement the sugarcane crop and may be an alternative feedstock in areas where sugarcane cannot be cultivated due to inadequate climate, soil or other factors.

\section{CONCLUSIONS}

An experimental protocol for finding the best conditions for granular starch enzymatic hydrolysis of sorghum grains at low enzyme loads was successfully developed, resulting in an overall conversion efficiency of $99.3 \%$. An ethanol concentration of 105.8 g. $\mathrm{L}^{-1}$ was attained at $24 \mathrm{~h}$ of fermentation. This result is of considerable practical importance from the economic standpoint, since the production cost of ethanol is mainly derived from the raw material and energy costs. High ethanol yield $\left(0.499 \mathrm{~g} \cdot \mathrm{g}^{-1}\right)$ and volumetric productivity $\left(4.41 \mathrm{~g} . \mathrm{L}^{-1} \cdot \mathrm{h}^{-1}\right)$ were reached in fermentation, demonstrating that sorghum can be an alternative for Brazil and other countries, since it is a culture that adapts to different soil types and climate. Furthermore, the production of bioethanol from corn is a mature and dominant industrial process in other countries, which bears similarity to the technology for the production of sorghum ethanol. This represents an advantage for eventual industrial implementation. Also, in the Brazilian context, the ethanol from sorghum grains can be deployed in Brazilian plants without major adjustments, particularly in the periods between harvest seasons.

\section{ACKNOWLEDGMENTS}

The authors acknowledge the Brazilian Council for Research (CNPq); the Rio de Janeiro State Foundation for Science and Technology (FAPERJ); the Brazilian Petroleum Company (PETROBRAS) for scholarship and other financial supports and Monsanto Company for the feedstock supply.

\section{NOMENCLATURE}

$\begin{array}{ll}\text { TRS } & \text { Total Reducing Sugars } \\ \text { RSB } & \text { Reducing Sugars in Blank } \\ \text { RSC1 } & \text { Reducing Sugars in Control 1 } \\ \text { RSC2 } & \text { Reducing Sugars in Control 2 } \\ \text { V }_{\mathrm{t}} & \text { Total Volume } \\ \text { DGW } & \text { Dry Grain Weight }\end{array}$

\begin{tabular}{|c|c|c|}
\hline RSP & $\begin{array}{l}\text { Reducing Sugars Produced } \\
\text { in the Hydrolysis of } \\
\text { Sorghum Grains }\end{array}$ & g. $\mathrm{L}^{-1}$ \\
\hline TRS & $\begin{array}{l}\text { Theoretical Reducing } \\
\text { Sugars from Starch in } \\
\text { Sorghum Grains }\end{array}$ & g. $L^{-1}$ \\
\hline $\mathrm{Y}_{\mathrm{P} / \mathrm{S}}$ & Ethanol Yield & g. $g^{-1}$ \\
\hline $\mathrm{P}$ & Final Ethanol Concentration & g. $\mathrm{L}^{-1}$ \\
\hline $\mathrm{P}_{0}$ & $\begin{array}{l}\text { Initial Ethanol } \\
\text { Concentration }\end{array}$ & g. $\mathrm{L}^{-1}$ \\
\hline $\mathrm{S}_{0}$ & $\begin{array}{l}\text { Initial Glucose } \\
\text { Concentration }\end{array}$ & g. $\mathrm{L}^{-1}$ \\
\hline $\mathrm{S}$ & Final Glucose Concentration & g. $L^{-1}$ \\
\hline $\mathrm{Q}_{\mathrm{P}}$ & $\begin{array}{l}\text { Volumetric Ethanol } \\
\text { Productivity }\end{array}$ & g. $L^{-1} \cdot h^{-1}$ \\
\hline $\mathrm{T}_{\mathrm{f}}$ & Total Fermentation Time & $\mathrm{h}$ \\
\hline Smd & Sauter mean diameter & $\mathrm{mm}$ \\
\hline $\mathrm{j}$ & $\begin{array}{l}\text { Subscript Indicating the jth } \\
\text { Granulometric Class }\end{array}$ & \\
\hline $\mathrm{W}$ & Weight Fraction & \\
\hline $\mathrm{d}_{\mathrm{p}}$ & Particle Diameter & $\mathrm{mm}$ \\
\hline $\mathrm{N}$ & $\begin{array}{l}\text { Number of Granulometric } \\
\text { Classes }\end{array}$ & \\
\hline
\end{tabular}

\section{REFERENCES}

Alexandre, H. and Charpentier, C., Biochemical Aspects of Stuck and Sluggish Fermentation in Grape Must. Journal of Industrial Microbiology and Biotechnology, 20, 20-27 (1998).

Almodares, A. and Hadi, M. R., Production of bioethanol from sweet sorghum: A review. African Journal of Agricultural Research, 4, (9), 772-780 (2010).

Al-Rabadi, G. J. S., Gilbert, R. G., Gidley, M. J., Effect of Particle Size on Kinetics of Starch Digestion in Milled Barley and Sorghum Grains by Porcine Alpha-Amylase. Journal of Cereal Science, 50, 198-204 (2009).

Altintaş, M. M., Ülgen, K. O., Kirdar, B., Önsan, I. Z., and Oliver, S. G., Improvement of Ethanol Production from Starch by Recombinant Yeast Through Manipulation of Environmental Factors. Enzyme and Microbial Technology, 31, 640-647 (2002).

Belton, P. S. and Taylor, J. R. N., Sorghum and Millets: Protein Sources for Africa. Trends Food Science and Technology, 15, 94-98 (2004).

Bisson, L. F., Stuck and Sluggish Fermentations. American Journal of Enology and Viticulture, 50, 107-119 (1999).

Fang, Q. and Hanna, M. A., Experimental Studies for Levulinic Acid Production from Whole Kernel 
Grain Sorghum. Bioresource Technology, 81, 187-192 (2002).

Farrell, A. E., Plevin, R. J., Turner, B. T., Jones, A. D., O'hare, M., and Kammen, D. M., Ethanol Can Contribute To Energy and Environmental Goals. Science, 311, 506-508 (2006).

Fiori, L., Bassi, D., and Costa, P., Seed Oil Supercritical Extraction: Particle Size Distribution of the Milled Seeds and Modeling. Journal of Supercritical Fluids, 47, 174-181 (2008).

Fuwa, H., A New Method for Microdetermination of Amylase Activity by the Use of Amylose as the Substrate. Journal of Biochemistry, 41, 583-603 (1954).

Hohmann, S., Osmotic Stress Signaling and Osmoadaptation in Yeasts. Microbiology and Molecular Biology Reviews, 66, 300-372 (2002).

Ingledew, W. M. and Kunkee, R. E., Factors Influencing Sluggish Fermentations of Grape Juice. American Journal of Enology and Viticulture, 36, 65-75 (1985).

Lafon-Lafourcade, S., Larue, F., and RibereauGayon, P., Evidence for the Existence of "Survival Factors" as an Explanation for Some Pecularities of Yeast Growth, Especially in Grape Must of High Sugar Concentration. Applied Environmental Microbiology, 38, 1069-1073 (1979).

Mahasukhonthachat, K., Sopade, P. A., and Gidley, M. J., Kinetics of Starch Digestion in Sorghum as Affected by Particle Size. Journal of Food Engineering, 96, 18-28 (2010).

Maiorella, B. L., Blanch, H. W., and Wilke, C.R., Economic Evaluation of Alternative Ethanol Fermentation Processes. Biotechnology Bioengineering, 26, 1003-1025 (1984).

Pereira Jr., N. and Bu'lock, J. D., The Ionic Character of the Environment in the Flocculation of Pichia stipitis. Brazilian Journal of Microbiology, 25, 51-56 (1994).

Rooney, W. L., Blumenthal, J., Bean, B., and Mullet, J. E., Designing Sorghum as a Dedicated Bioenergy Feedstock, Biofuels. Bioproducts and Biorefining, 1, 147-157 (2007).

Silva-Filho, E. A., Melo, H. F., Santos, S. K. B., Resende, A. M., Simões, D. A. and Morais Jr., M. A., Isolation by Genetic and Physiological Characteristics of a Fuel-Ethanol Fermentative
Saccharomyces cerevisiae Strain with Potential for Genetic Manipulation. Journal of Industrial Microbiology, 32, 481-486 (2005).

Shewale, S. D. and Pandit, A. B., Enzymatic Production of Glucose from Different Qualities of Grain Sorghum and Application of Ultrasound to Enhance the Yield. Carbohydrate Research, 344, 52-60 (2009).

Smith, C. W. and Frederiksen, R. A., Sorghum: Origin, History, Technology and Production, p. viii. Wiley, New York (2000).

Southgate, D. A. T., Determination of Food Carbohydrates. Elsevier Applied Science, Second Ed. Barking, London (1991).

Summer, J. B., The Determination of Sugar in Diabetic Using Dinitrosalicylic Acid. Journal of Biological Chemistry, 61, 287-290 (1929).

Wang, D., Bean, S., McLaren, J., Seib, P., Madl, R., Tuinstra, M., Shi, Y., Lenz, M., Wu, X., and Zhao, R., Grain Sorghum is a Viable Feedstock for Ethanol Production. Journal of Industrial Microbiology and Biotechnology, 35, 313-320 (2008).

Wu, X., Zhao, R., Bean, S. R., Seib, P. A., Mclaren, J. S., Madl, R. L., Tuinstra, M., Lenz, M. C., and Wang, D., Factors Impacting Ethanol Production from Grain Sorghum in the Dry-Grind Process. Cereal Chemistry, 84, 130-136 (2007).

Wu, X., Zhao, R., Wang, D., Bean, S. R., Seib, P. A., Tuinstra, M. R., Campbell, M., and O'brien, A., Effects of Amylose, Corn Protein and Corn Fibers Contents on Production of Ethanol from Starch Rich Media. Cereal Chemistry, 83, 569575 (2006).

Xiaojing, X., Limin, C., and Xun, C., Elementary Flux Mode Analysis for Optimized Ethanol Yield in Anaerobic Fermentation of Glucose with Saccharomyces cerevisiae, Chinese Journal of Chemical Engineering, 16, 135-142 (2008).

Zhao, R., Ban, S. R., Wang, D., Park, S. H., Schober, T. J., and Wilson, J. D., Small-Scale Mashing Procedure for Predicting Ethanol Yield of Sorghum Grain. Journal of Cereal Science, 49, 230-238 (2009).

Zheng, Y., Pan, Z., Zhang, R., and Wang, D., Enzymatic Saccharification of Dilute Acid Pretreated Saline Crops for Fermentable Sugar Production. Applied Energy, 86, 2459-2465 (2009). 